\title{
The Experimental Tourism Satellite Account for the United Kingdom (E- UKTSA)
}

Tullio Buccellato, Dominic Webber and Sean White

Office for National Statistics

\section{Summary}

Since its formation within the Office for National Statistics (ONS) in August 2008, the Tourism Intelligence Unit (TIU) has been working on the creation of an Integrated System of Tourism Statistics (ISTS), whose core component is represented by the E-UKTSA (Experimental UK Tourism Satellite Account). This paper describes the construction of the E-UKTSA and presents some headline figures derived from it. The paper concludes by highlighting possible avenues for improvements to the E-UKTSA and suggesting future research connected with the satellite account framework.

\section{Introduction}

The tourism sector has increasingly captured attention in the UK, particularly in the period following the economic crisis which witnessed a significant growth in domestic tourism ${ }^{1}$ (see Webber et al 2010). The measurement of the economic impact of tourism has, accordingly, acquired a central role for many tourism organisations and other parties interested in having precise figures relating to tourism activities. This measurement requires consideration of the supply and the demand side of tourism economic activity as well as a need to ensure comparability with other economic activities in the economy and with tourism elsewhere.

The Tourism Satellite Account (TSA) is a technique that seeks to calculate the value of tourism in a way that allows such comparisons. This paper details the development of a TSA for the UK, a process that has been underway at the ONS over the last twelve months through the work of the Tourism Intelligence Unit (TIU).

The TIU was established within the ONS in August 2008 with funding from the nine English Regional Development Agencies (RDAs) and Visit England. The aim of the unit is to improve tourism statistics, especially those that relate to the tourism industry, the visitor economy and the economic impact of tourism. 
Initially, the TIU was charged with reviewing the various TSAs that have been produced in the UK and elsewhere. Additionally, the Unit has been exploring how TSAs might be used and developed in future. As this review process progressed, the importance of a TSA in contributing to an ISTS became clear. Indeed, where such integrated systems exist (examples include Canada and New Zealand), the TSA is regarded as the central component and is used as a tool to not only assess the value of tourism but also to identify gaps in knowledge of the sector. Furthermore, the TSA can be employed to show linkages between tourism and other parts of the economy within a National Accounting framework, for example Environmental Accounts.

The next section describes in more detail the TSA framework. The third section then provides detail on the compilation of the core tables of the TSA, detailing the data sources used in each table and presenting headline figures. The fourth section focuses on the unresolved issues with data which make it difficult to publish the TSA without the label 'experimental'. The final section suggests further research.

\section{The TSA framework}

The measurement of tourism can be achieved using two perspectives - either considering it as a demand side or as a supply side phenomenon. The demand side of the tourism sector is related to the activities of visitors and their consumption behaviours. The supply side refers instead to the tourism related industries as defined by recommended international recommendations. One of the main advantages of the TSA methodology is to allow for a reconciliation of these two elements of tourism measurement.

In general terms, a satellite account is an extension to a System of National Accounts (SNA) which enables an understanding of the size and role of economic activity within a particular sector which can not be included explicitly within the SNA. In essence, the TSA allows for the separation of expenditure of residents and tourists, which are treated as one within the SNA.

This separation enables the estimation of key variables such as how much individual industries depend upon tourists, and, by extension, the amount of economic output (value-added) and employment supported by tourists. It is the case that the supply and use of goods and services for tourism purposes, including value added and employment generated, can be shown systematically by a supply and use table. This is possible as long as tourism characteristic products and industries are distinguished from the additional, or secondary, tourism-connected products. The internationally agreed primary tourism characteristic products are shown in Box 1: 


\section{Box 1 Primary tourism characteristic products ${ }^{1}$}

- Accommodation services for visitors

- Food and beverage serving services

- Railway passenger transport services

- Road passenger transport services

- Water Passenger transport services

- Air passenger transport services

- Transport equipment rental services

- Travel agencies and other reservation services

- Cultural services

- Sports and recreational services

- Country-specific tourism characteristic goods

- Country-specific tourism characteristic services

Note

1. Based on the Tourism Satellite Account Recommended Methodological Framework (UNWTO, EUROSTAT, OECD, 2008)

The TSA can be simply described as a collection of information ordered in 10 tables, the first six of which can be considered as core tables (see Tourism Satellite Account Recommended Methodological Framework, UNWTO, EUROSTAT, OECD, 2008, hereafter TSA:RFM 2008). The first three tables ${ }^{2}$ summarize the demand side information categorizing it respectively in inbound tourism expenditure, domestic tourism expenditure and outbound tourism expenditure. The fourth table provides the total internal tourism expenditure by combining tables one and two. The fifth table contains supply side data and the sixth table reconciles demand and supply figures as displayed in tables four and five. The seventh table collects data concerning the employment in tourism industries. The eighth table collects data on the tourism gross fixed capital formation of tourism industries and other industries. The ninth table displays figures on tourism collective consumption by products and levels of government. The tenth and final concludes showing the non-monetary indicators. The first six are generally considered to be the core tables of the TSA in that they can be directly linked to the SNA. The ten tables of the TSA are summarised in Box 2: 


\section{Box 2 Tourism Satellite Account: summary of tables}

Table 1: Inbound tourism expenditure

Part of aggregate demand; such as an export

Table 2: Domestic tourism expenditure

Part of domestic total consumption

Table 3: Outbound tourism expenditure

Generally linked to other TSA tables so is often not estimated

Table 4: Domestic 'tourism final consumption'

Synthesised from Tables 1 and 2

Table 5: Production of tourism commodities

The services and products of 'tourist related' industries but also of non-tourist related industries

Table 6: Domestic supply and consumption by product

A reconciliation of Tables 4 and 5 . The heart of the TSA

Table 7: Employment and labour use

Not Currently Reported

Table 8: Tourism Fixed capital formation (investment)

Not Currently Reported

Table 9: Tourism Collective Consumption

Not Currently Reported

Table 10: Non-monetary Indicators

such as tourism volumes/nights; types of tourist etc. Structure can reflect most useful

indicators.

In conclusion, the TSA can be considered an accounting procedure summarizing a complex and substantial amount of information as derived by other surveys or data sources. If the ordering of the information is relatively simple (reporting and apportioning), the collection of the information is a time consuming and often expensive procedure that countries are not always prepared to carry out.

Within the TSA, data are ordered according to a demand/supply framework and the most important output is represented by the reconciliation of the expenditure dimension with its production counterpart. It follows that the central component of the TSA is Table 6, where demand-to-supply ratios are reported industry by industry and for the whole UK economy (see Box 3). This has been referred to as the 'heart' of the TSA. 


\section{Box 3 Linkages between the TSA tables}

Table 1 - Inbound Tourism Expenditure

Including overnight visitors and excursionists. Main data source: IPS.

Table 2 - Domestic

\section{Tourism Expenditure}

Including overnight visitors, excursionists and outbound trips with UKTS, England Nature and Jones et al (2004) representing the main data sources for the three components respectively.

Table 6 - Total domestic production and tourism internal consumption (at purchaser's prices)

\section{Table 3 - Outbound}

Tourism Expenditure (not

strictly necessary for

reconciliation)

Table 4 - Internal tourism

consumption by product

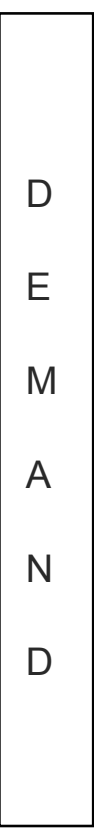

A

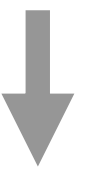

RECONCILIATION

Table 5 - Production account of tourism industries and other industries (at basic prices)

With the SUT and the ABI representing the main data sources.
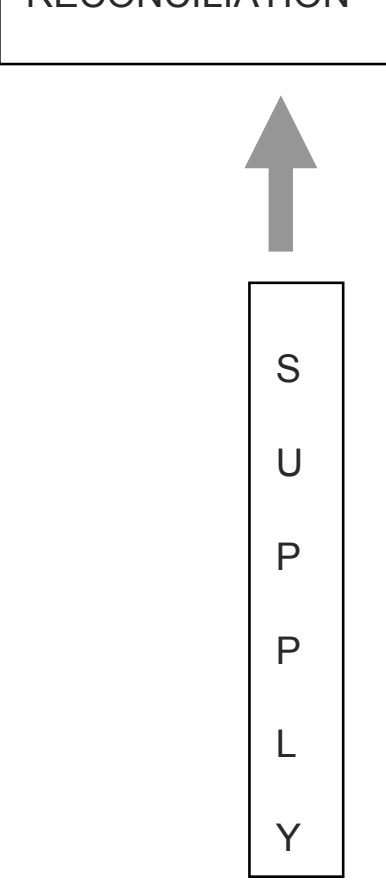


\section{The compilation of TSA Core Tables}

This section refers to the production of the six core tables of the TSA for the reference year of 2006 in the United Kingdom. These form the E-UKTSA and are included in full in the Annex of this article.

\section{Table 1: Inbound tourism expenditure by products and classes of visitors}

Table 1 (summarised in Figure 1), which measures inbound tourism expenditure, was constructed using data from the 2006 International Passenger Survey (IPS). The Family Spending Survey 2008 was used to augment the content of the table where IPS data was not sufficient.

The headline output of Table 1, total expenditure of inbound visitors, is sourced from Table 2.02 of the IPS annual report, Travel Trends 2006. This report also included the expenditure of inbound nil-night visitors, or excursionists, in Table 2.13. As visitors are either overnight visitors or excursionists, the expenditure of overnight visitors was acquired by simply subtracting the expenditure of nil-night visitors from the expenditure of all visitors.

Disaggregating expenditure by product purchased requires the use of an expenditure trailer from the IPS. The last such trailer was carried out in 1997 so this is an area where improvements to the data inputs to the TSA could be made. Work is on-going within ONS to assess the feasibility of collecting more detailed expenditure data using the IPS. In the absence of more up to date information the expenditure trailer for 1997 is used here.

As suggested by the TSA Recommended Methodological Framework (TSA:RMF, 2008), expenditure must be disaggregated between the product groups shown in Box 1. For Table 1, the IPS expenditure trailer was used to do this. Shares of expenditure by product to total expenditure from the 1997 expenditure trailer were applied to the totals from 2006. Apart from the fact that the expenditure trailer is out of date, three more issues arise from its use.

Firstly, there is no distinction between the spend of same day excursionists and overnight visitors. Therefore, in the E-UKTSA these two groups' spend on products are in the same proportions, with the exception of accommodation services, which excursionists, by definition, spend nothing on.

The second issue is that the expenditure trailer breakdown is not sufficient to meet the product breakdown as laid out by TSA RMF 2008. Therefore the ONS' Family Spending Survey 2008 was used to fill in some of these information gaps. For example, the expenditure trailer reported how much was spent on taxi and car hire together. However, for TSA purposes this needs to be separated in order for taxis to be included in road passenger transport services, and car hire is included in transport equipment rental services. The Family Spending Survey provided the ratio of spending between taxis and car hire, which was then applied to the expenditure trailer share. This, however, implies an assumption that domestic residents' spending patterns are the same as those of international visitors. 
The final issue is that the expenditure trailer doesn't report on expenditure on travel agencies and other reservation services. Therefore, the E-UKTSA draws on a pilot TSA for the UK for 2000 (see Jones et al 2004), by using the share of expenditure on travel agencies of the total expenditure of inbound visitors for that year.

To rectify these three issues fully would ultimately require an update of the IPS expenditure trailer, which will be discussed in greater detail later.

The headline figure of Table 1, total expenditure by inbound visitors to the UK in 2006 was $£ 16$ billion, with 1.1 per cent spent by excursionists, and the remainder attributable to overnight visitors. Accommodation services drew the greatest expenditure from visitors, at approximately $£ 5.1$ billion, while Travel agencies and other reservation services comprise the smallest amount of revenue for inbound residents as these services are normally drawn upon in the country of origin of inbound visitors. Patterns of expenditure are shown in Figure 1.

\section{Figure 1 Inbound tourism expenditure by product and class of visitor, 2006}

$£$ millions

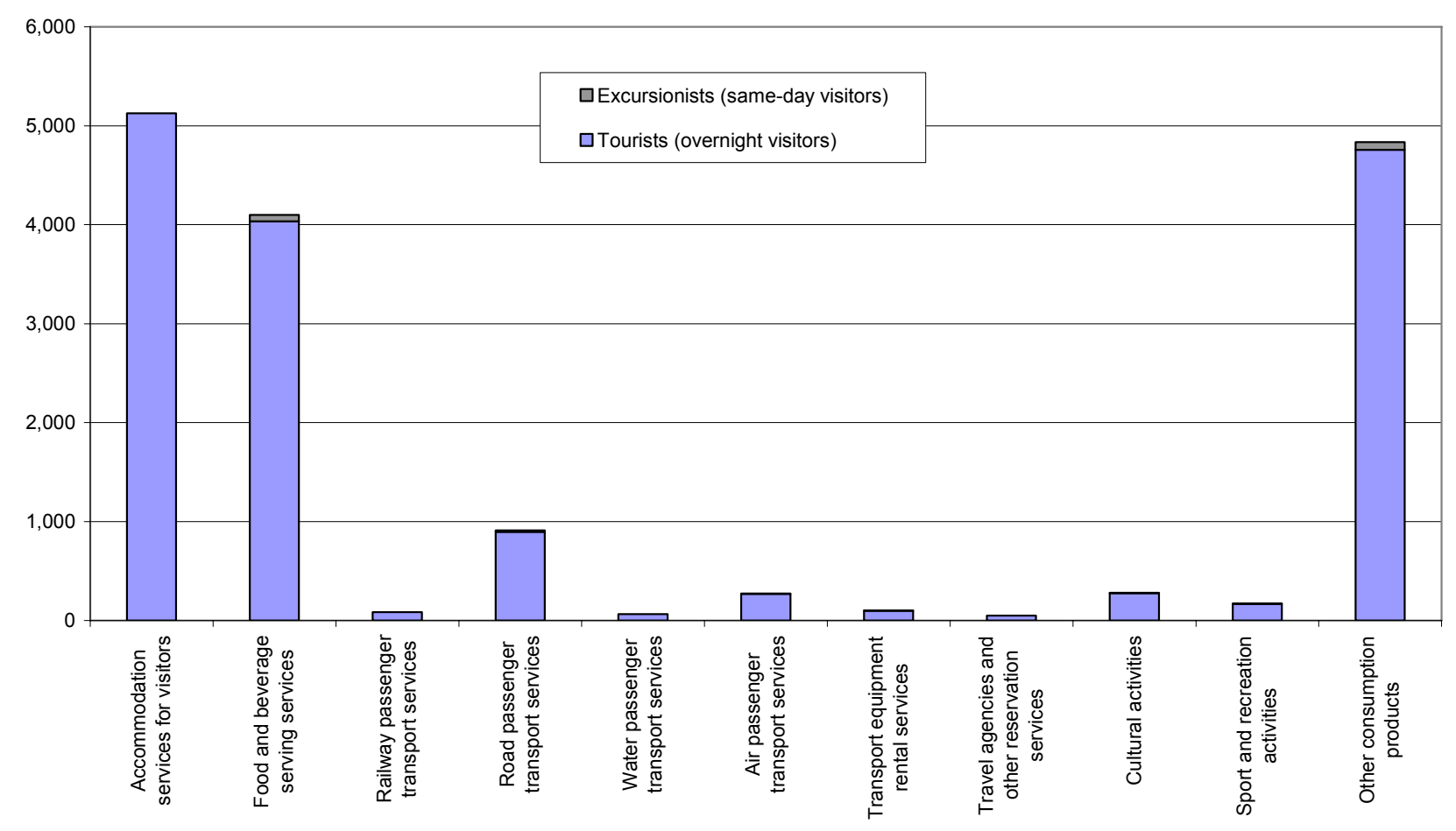

Source: Table 1 of the E-UKTSA 


\section{Table 2: Domestic tourism expenditure by products, classes of visitors and types of trip}

Table 2 (summarised in Figure 2), which measures domestic tourism expenditure, utilises a variety of different sources and includes two sources of such expenditure: domestic residents taking trips within the UK and domestic residents who are travelling abroad. The first of these two aspects of Table 2 is split between overnight stays and same day excursionists but the second is not.

Expenditure of overnight visitors taking trips within the UK is sourced from the United Kingdom Tourism Survey (UKTS) 2006, which also provides an expenditure breakdown by product purchased. Although the UKTS provides this breakdown, a similar problem to the one faced in TSA Table 1 arises, in that it is not adequate to provide the breakdown required by the TSA:RMF 2008. Therefore, shares are calculated from the ONS Supply and Use Tables (SUT), and in particular the 'Final demand of households' element. For example, the UKTS expenditure data only reports expenditure on travel costs to and from the destination, and has to be broken down further using the final demand of households. This of course is problematic, as the expenditure of households as a group is likely to be different to the expenditure of tourists.

Where the SUT is unable to completely disaggregate the total expenditure, Table 2, in similar fashion to Table 1, draws on the Family Spending Survey 2008.

For excursionists taking trips within the UK, the most recent survey which is suitable to use is the English Leisure Visits Survey (ELVS) of 2005. This survey was carried out in England only and projections provided by Visit Britain were used for Wales and Scotland. A 2003 TSA for Northern Ireland $(\mathrm{NI})^{3}$ completes the picture for the UK. The $\mathrm{NI}$ breakdown by product is in line with TSA: RMF 2008 but there is no suitable breakdown for the ELVS 2005. Therefore, the E-UKTSA again uses shares from the pilot TSA for 2000 . To obtain excursionist expenditure in 2006 prices, both the $\mathrm{NI}$ and the rest of the UK figures were inflated, making use of ONS price indices for each separate product. For example, the price index for 'Passenger transport by air' was directly applied to the air transport products purchased by visitors.

The component of Table 2 measuring domestic tourism expenditure by domestic residents who are travelling abroad captures expenditure of UK residents on UK industries for the sole purpose of travelling outbound, or away, from the UK. This is characterised by expenditure on outbound transport services and travel agencies. At present this data is not collated centrally and, as a result, the E-UKTSA uses inflated figures from the pilot TSA 2000 for the UK whilst also accounting for the trend in outbound visitors over the time period (see Jones et al 2004). This study does not split expenditure between excursionists and overnight visitors and, as a result, this experimental TSA is similarly constrained.

The total expenditure of domestic residents making domestic visits is approximately $£ 66$ billion, with 68 per cent being consumed by excursionists and the rest by overnight visitors. As might be expected, the spending patterns of domestic visitors differ from those of inbound visitors.

Accommodation for domestic visitors only accounts for 10 per cent of total expenditure, while food and beverage services draw the most revenue, almost $£ 19$ billion or 29 per cent of total 
expenditure. Perhaps surprisingly, air travel accounts for 3 per cent of total expenditure of domestic visitors travelling in the UK. Indeed, it is much larger in magnitude than railway travel, which one might consider a more traditional mode of transport for the UK holidaymaker, which generates almost $£ 2$ billion of revenue. Unsurprisingly, air travel accounts for 60 per cent of total domestic expenditure on outbound trips, at approximately $£ 9.4$ billion.

\section{Figure 2 Domestic tourism expenditure by products, classes of visitors and types of trips}

$£$ millions

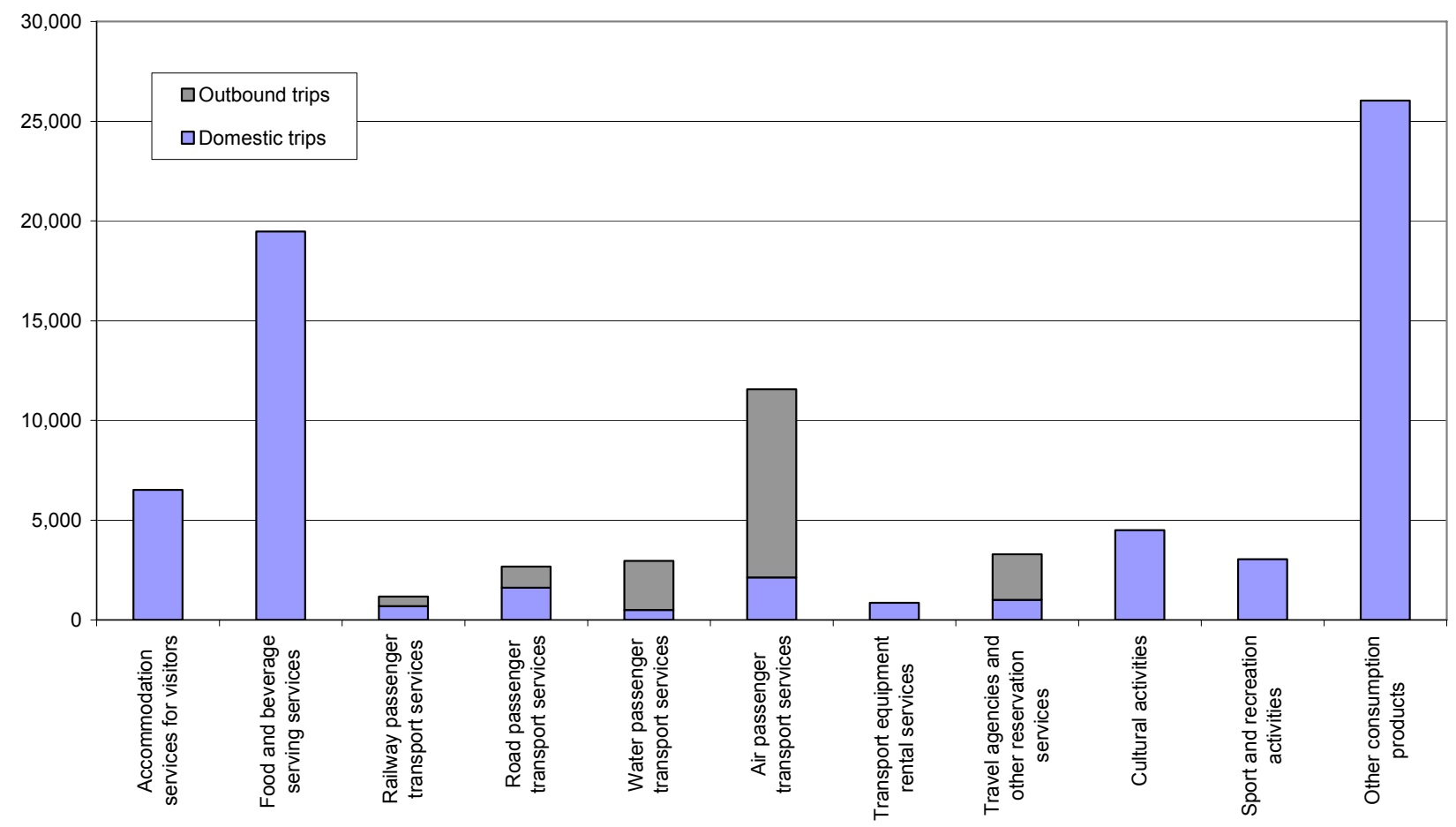

Source: Table 2 of the E-UKTSA

\section{Table 3: Outbound tourism expenditure by products and classes of visitors}

Table 3 (summarised in Figure 3) measures the expenditure of UK residents, outside the UK, on outbound trips. As the spending occurs outside the UK, it is not included in Table 6, the reconciliation of tourism demand and supply, which is used to determine the economic impact of tourism in the UK. Nonetheless, the information it conveys is important from a balance of payments perspective as it shows the imports of tourism goods and services as a result of final demand from UK residents.

The headline figure, the total expenditure of all types of visitors on outbound trips, is taken from the IPS in Table 3.02. Similarly, the total expenditure of excursionists is from the IPS, from Table 3.13. The 1997 expenditure trailer used for Table 1 is not appropriate here as it measures the 
expenditure of tourists visiting the UK. Therefore two ONS sources are used to disaggregate the total expenditure of all types of visitors: the SUT, and the Annual Business Inquiry (ABI).

The SUT disaggregates spending between accommodation and food services; the transport categories; and recreational services by taking the shares of imports of goods and services for these. To further disaggregate accommodation and food; sport and culture; and transport rental and travel agencies into their separate components required their respective shares of gross value added obtained from the ABI. The only category of product which could not be estimated is 'other consumption products'. This was resolved by using the 2000 pilot TSA for the UK.

The breakdown of expenditure by outbound excursionists on 'other consumption products' was obtained by applying the same shares as those identified for domestic excursionists. This assumes that the two types of excursionists purchase goods in the same proportions. Finally, the expenditure of overnight visitors was obtained by subtracting the expenditure of excursionists from total expenditure.

\section{Figure 3 Outbound tourism expenditure by products and classes of visitors}

$£$ millions

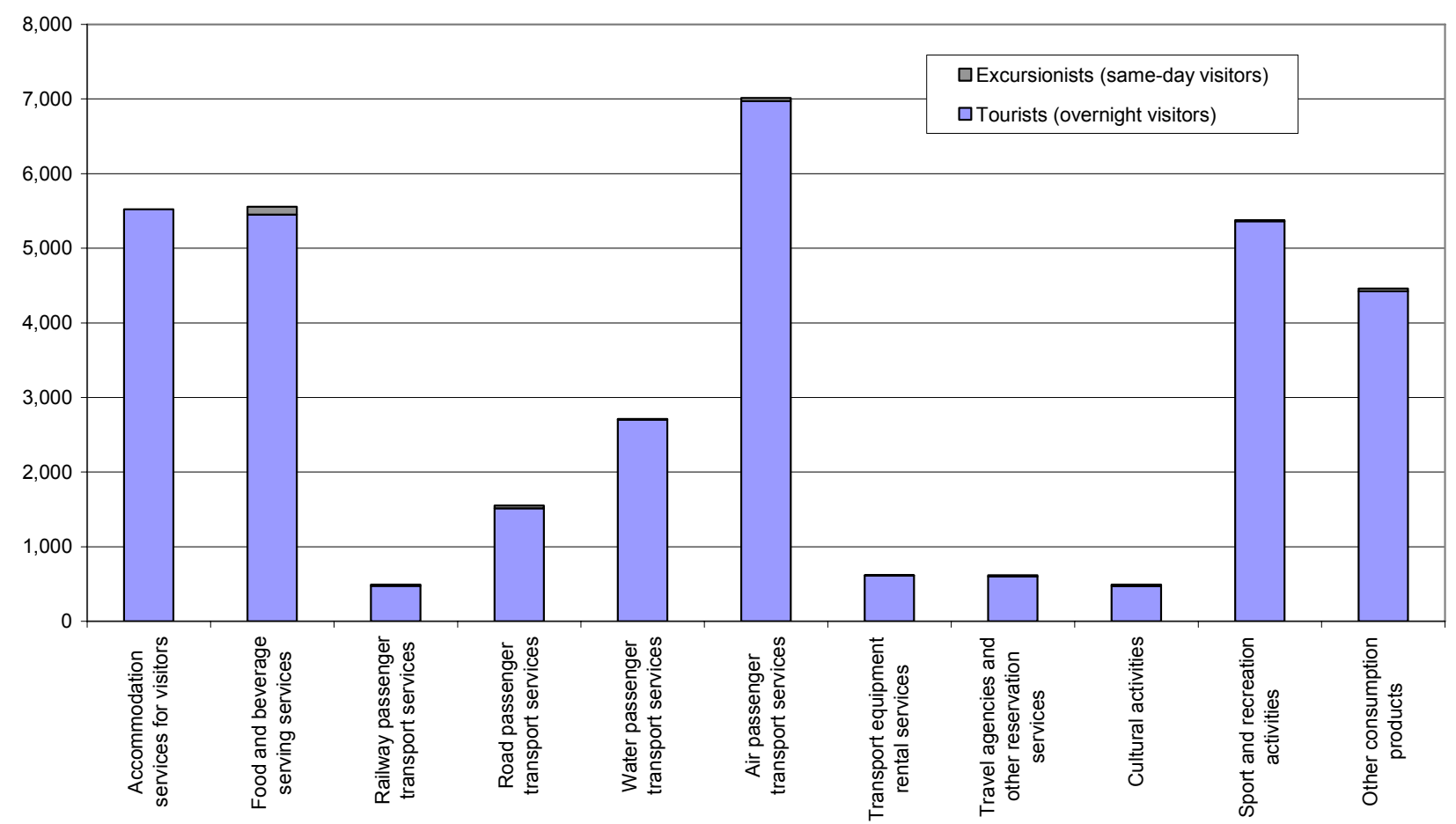

Source: Table 3 of the E-UKTSA

The total expenditure of outbound visitors in 2006 was $£ 34.5$ billion, with 99 per cent of this due to overnight visitors. The largest category of spending, with 20 per cent of total spend is air 
passenger transport services. This might be representative of the fact that people purchase flights from foreign airlines, like Ryanair for example, when leaving the country. Purchases from foreign companies to leave the UK should be included in Table 3 as opposed to the section for resident visitors travelling in Table 2. The other major categories of spend of outbound visitors are food and beverage serving services; accommodation services and sports and recreational services accounting for 16.2 per cent, 16.0 per cent and 15.6 per cent respectively.

\section{Table 4: Internal tourism consumption by products}

Table 4 (summarised in Figure 4), which measures internal tourism consumption, is an aggregation of Table 1 and Table 2. In the E-UKTSA, 'Other components of tourism consumption' has not been completed. This column represents elements such as the maintenance of second homes. There is little reliable source data upon which to compute the importance of second homes and as a result this is not included in this experimental account.

Food and beverage, air travel, and other consumption products represent the products which visitors demand the most with amounts of $£ 23.6$ billion, $£ 11.8$ billion, and $£ 30.9$ billion respectively.

\section{Figure $4 \quad$ Internal tourism consumption by products}

$£$ millions

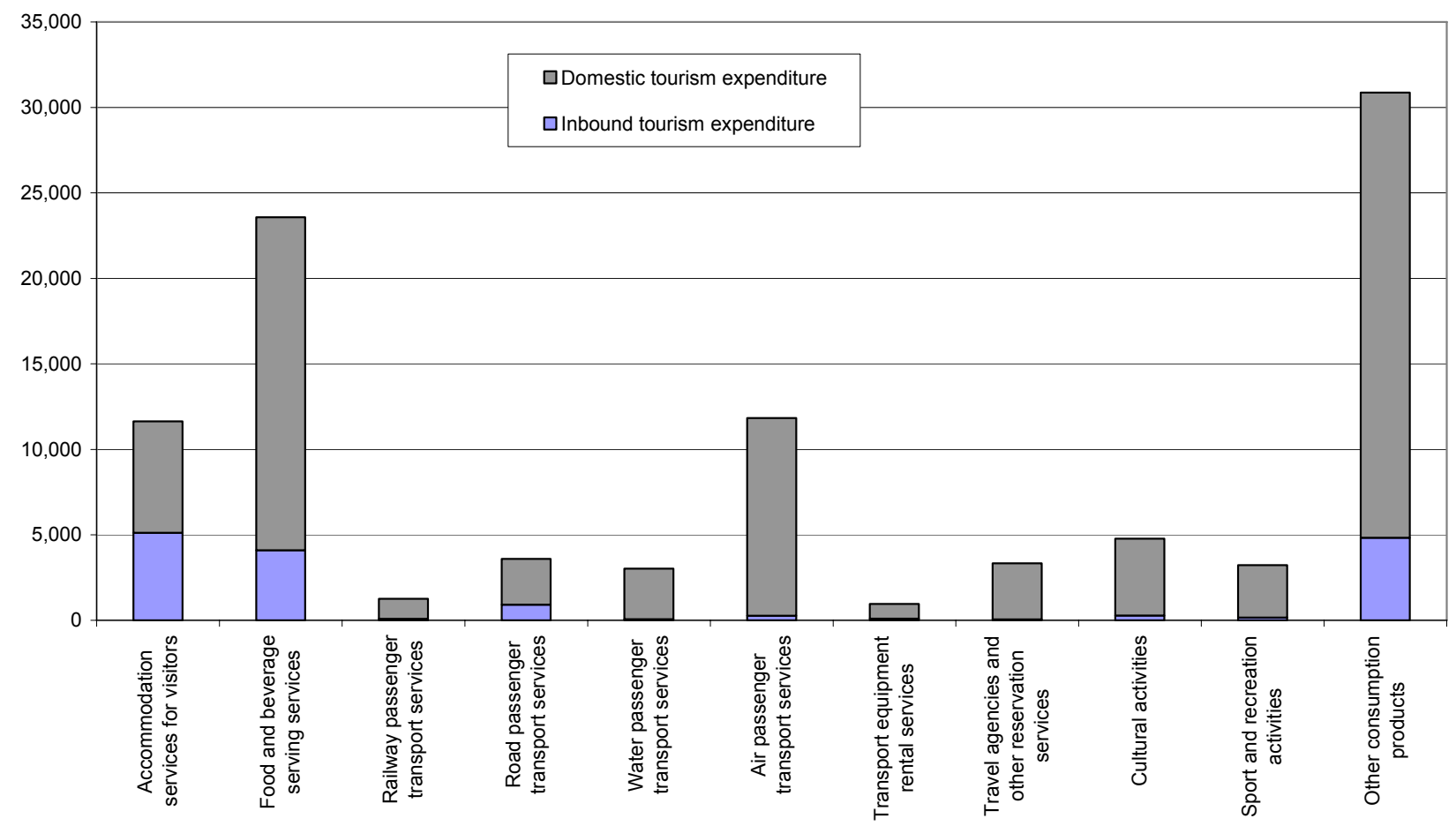

Source: Table 4 of the E-UKTSA 
Table 5: Production accounts of tourism industries and other industries (at basic prices)

Table 5 (summarised in Figure 5) displays figures on the supply side of tourism which are derived from two main sources: the $2006 \mathrm{ABI}$ (converted to SIC07 codes), and the SUT. These sources are combined with the Make Matrix (MM) $2004^{3}$ and some information derived from the pilot 2000 UK TSA of Jones et al (2004).

Firstly, figures concerning the tourism industries are directly extracted from the SUT. In particular, figures can be tracked sector-by-sector for total output at basic prices, total intermediate consumption at purchasers' prices and gross value added at basic prices.

The MM 2004 is then used to calculate what proportion of each of the tourism related products is exactly produced by its corresponding industry, or by other industries in the economy. For instance, the MM 2004 describes what proportion of food and beverage serving services are produced by the food and beverage serving industry, and what is produced by other industries, tourism or otherwise.

\section{Figure 5 Production accounts of tourism industries and other industries}

$£$ millions

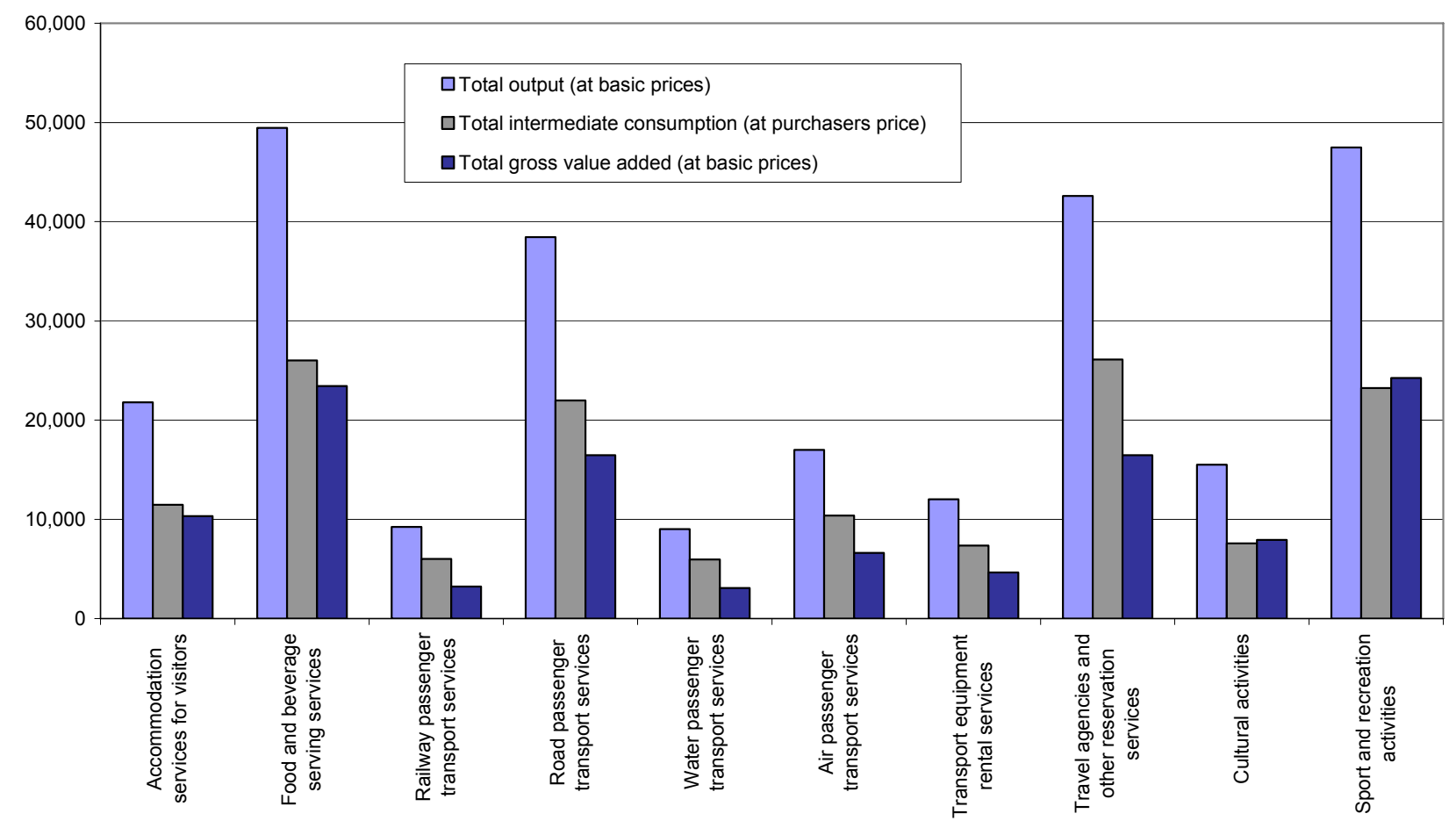

Source: Table 5 of the E-UKTSA

The figures derived from the SUT are produced according to the 2003 Standard Industrial Classification (SIC) and we, therefore, make use of a version of the $A B I$ from 2006 which has been converted to SIC 2007 categories in order to split the former SIC 2003 into the SIC 2007 industries. 
This allows for the production of the E-UKTSA according to the most recent international recommendations.

Table 5 shows, for example, that the accommodation industry had an output of $£ 21.8$ billion in 2006 , with approximately $£ 280$ million of accommodation service products produced by nontourism industries. With $£ 11.5$ billion of intermediate consumption, the gross value added of the accommodation industry is calculated at $£ 10.3$ billion.

\section{Table 6: Total domestic supply and internal tourism consumption (at purchaser prices)}

Table 6 (summarised in Figure 6) inherits the figures displayed in Tables 4 and 5 for the reconciliation of demand and supply. In addition to the data reported in Table 5, data concerning imports and taxes less subsidies on products nationally produced or imported are also reported to obtain the total domestic supply at purchasers' prices (all these figures are again obtained from the SUTs and apportioned in SIC 2007 according to the ABI 2006 converted in SIC 2007 codes).

\section{Figure 6 Total domestic supply and internal tourism consumption (at purchaser prices)}

$£$ millions

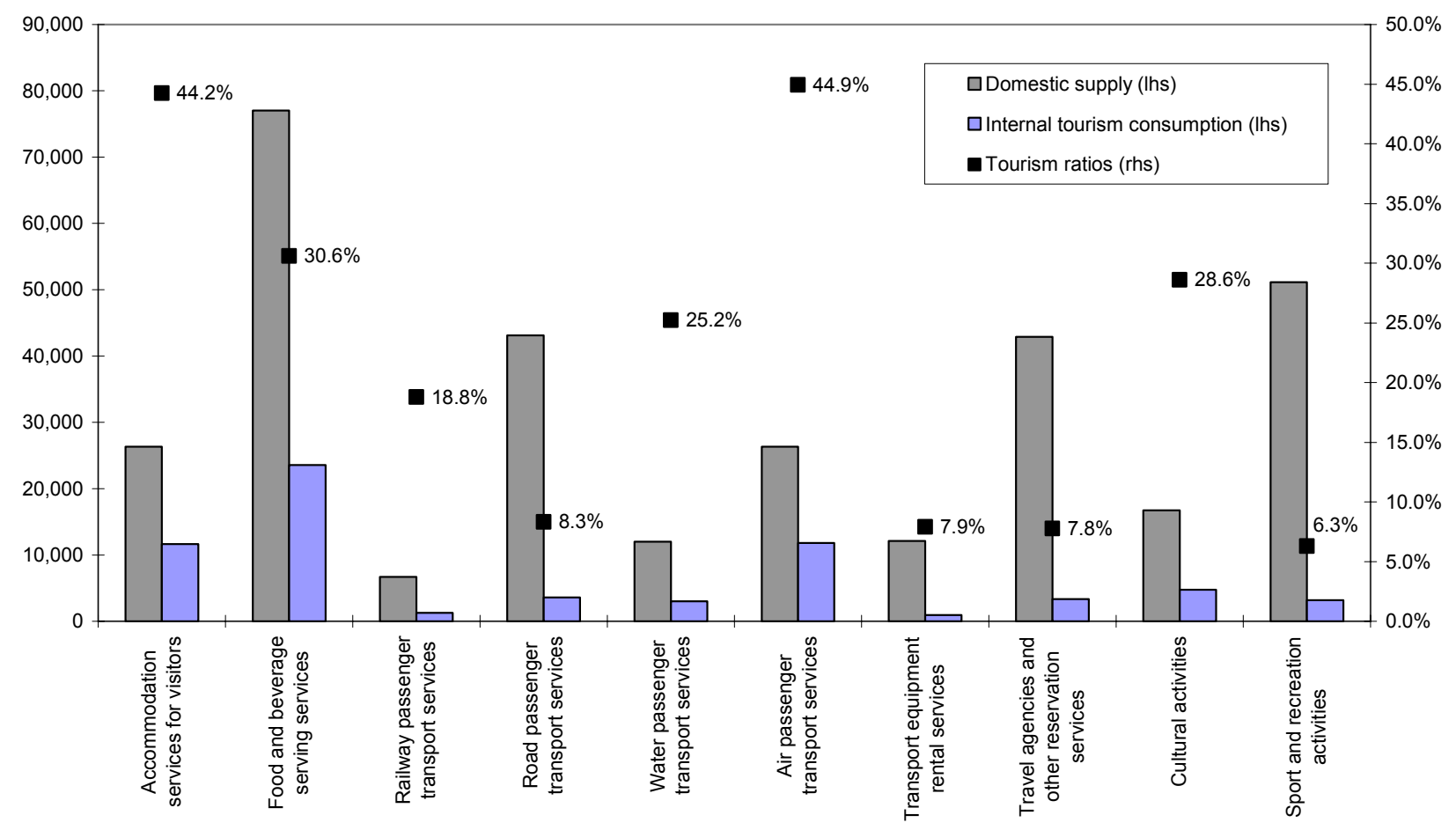

Source: Table 6 of the E-UKTSA 
Table 6 reports the demand to supply ratios of the tourism industry (the final column in the table which is entitled 'Tourism Ratios'). The estimated ratio for total demand to supply is 3.3 per cent. This implies that this proportion of the output of the tourism and non-tourism industries is consumed by visitors to and of the UK. This allows the production of aggregates, particularly Tourism Direct Gross Value Added (TDGVA). A simplified method of estimating this is to use the demand to supply ratio and apply it to the total GVA of domestic producers (in basic prices) reported in Table 6. This method has been reported on previously by Buccellato, Webber, White, Ritchie and Begum (2010) and gives a figure of $£ 39.2$ billion for TDGVA. The TIU is currently working on an updated TSA for the UK that will refine the measurement of this aggregate, particularly considering the influence of non-tourism industries in its calculation. The use of the term 'direct' in this aggregate refers to the fact that the TSA only measures that part of value added (by tourism industries and other industries) due to the consumption of visitors and leaves aside the indirect and induced effects that such a consumption might generate (TSA:RMF 2008).

Ratios for other industries are also calculated, for example the railway industry has a demand to supply ratio of 19 per cent which implies that almost a fifth of the output of the industry is consumed by UK tourism demand.

\section{Problems and limitations of the Experimental UK-TSA}

This experimental version of the TSA suffers a number of problems and limitations due to the lack of sources for some fundamental figures reported in the tables. This has required the use of some relatively out of date resources to fill the information gap.

The first such source is the use of an IPS Expenditure Trailer from 1997 in the central part of Table 1 to break down the inbound tourism expenditure among the different definitions of tourism consumption. Since 1997 tourism consumption habits have considerably changed, an example being the wider use of new technology (such as mobile phones) before and during the visiting period. Therefore, to improve the Table 1 there needs to be a regular update of the IPS expenditure trailer detailing the expenditure of products purchased by inbound visitors in line with the TSA RMF. It would also be useful to have a similar expenditure trailer for outbound visitors but this information would not be reported in Table 6 as it is not directly relevant to the impact of tourism on the UK economy. For the purposes of constructing a TSA the priority is to collect more detailed expenditure information in the IPS for inbound visitors. Some progress has been made in this area with pilot expenditure questions tested on the survey but a key problem is the expense and subsequent funding arrangements for the collection of this information.

Table 2 uses the ELVS 2005 and the NI TSA 2003 in order to report the total expenditure of day visitors. The lack of an up to date source of information on day visits is well recognised within the tourism sector. The TIU has been working with the national tourist boards in Great Britain to address this issue. Following extensive piloting work a new GB day visits survey will now be in the field in 2011. In Northern Ireland information on day visits is currently being collected separately but this uses a similar approach to the GB study. The degree of error due to the out of date nature 
of some of these key sources used in Table 1 and 2 is directly transmitted to Table 4 , as this is a synthesis of the first two TSA tables.

Furthermore, information on UK-based expenditure of UK residents travelling abroad is severely limited. The importance of this element of tourism expenditure is highlighted in the pilot TSA from 2000 , where it accounts for 16 per cent of total tourism demand. As a result the TIU is planning to direct more attention towards the accurate measurement of this element by investigating and using potential alternative data sources. For instance, the Chamber of Shipping (CoS) collects data on most of the activities of UK-based shipping companies, both for freight and passenger transport and, as the transport categories in the SUT do not differentiate between passenger and freight transport, any such insight into the respective shares would add great value to the TSA work.

Table 5 is heavily affected by the lack of an up to date MM. To fill the central part of the table, the only available source is a MM dated 2004. Table 5 is also based on a relatively sophisticated estimation procedure to convert the SIC03 coding of the SUT into the SIC07 format matching international recommendations, which could cause some problems in terms of determining how the splits are made between industries. By 2011 there will be an improvement on the supply side, when the SUT will be produced in the SIC07 classification, which incorporates breakdowns that are useful for the tourism sector (for example splitting hotels and accommodation from food and beverage which is not the case under the $\mathrm{SICO} 3$ classification).

Table 6 is a reconciliation of the demand and supply side data and therefore inherits all the problems of the information contained in Table 4 and in Table 5.

\section{Suggestions for further research}

There is further research that can be conducted, drawing from the TSA as a central component of an integrated system of tourism statistics. Much of this is now underway within the TIU and relates to three broad areas.

Firstly, it is possible to produce current values for the main figures relating to the demand side and the supply side of the TSA. Also in this edition of Economic \& Labour Market Review, Buccellato, Webber and White (2010) show how more recent TSA figures can be 'nowcasted'.

Secondly, it is possible to adopt a top-down approach to calculate regional figures from the TSA national figures. A bottom-up approach would provide more precise regional figures, but the topdown approach ensures comparability between regions and, furthermore, the total should correspond to that at the national level. The TIU has already published a proposed hybrid approach towards the measurement of the economic impact of tourism regionally (Buccellato, Webber, White, Ritchie and Begum 2010).

Finally, the updating and improvement of the TIU experimental TSA, will require also the additional draft of the remaining tables as suggested by the international recommendations (TSA:RMF 2008). The availability of data within the ONS would allow for the completion of Table 3 which relates to 'Outbound tourism expenditure by products and classes of visitors', Table 7 which details 
employment in the tourism industries (including self employed, employees, number of hours worked and number of FTEs, and Table 10 which comprises four tables relating to non-monetary indicators: a) number of trips and overnights by different forms of tourism and classes of visitors; $b$ ) inbound tourism- number of arrivals and overnights by mode of transport; c) number of establishments and capacity by types of accommodation, and d) number of establishments in tourism industries classified according to average number of jobs. The TIU is currently working on updating the TSA to the reference year 2008 and some of these elements will form part of that update process.

\section{Acknowledgements}

We would like to acknowledge the help of Dr. Calvin Jones of Cardiff University in the preparation of the TSA and Eddie Smith and Felix Ritchie of ONS for valuable comments on the paper.

\section{Notes}

1 The 'staycation' effect refers to UK households substituting foreign for domestic holidays. The depreciation of sterling in the second half of 2008 may be one factor that has further encouraged this.

2. Table three can be considered of secondary importance in that it does not contribute to the determination of the national tourism demand to supply ratio.

3. See Northern Ireland Tourism Board, Department for Enterprise, Trade and Investment (2007), Tourism in the Northern Ireland Economy.

4. See Stockholm Environment Institute (2008)

\section{Contact}

elmr@ons.gov.uk

\section{References}

Buccellato T, Webber D and White S (2010) 'A proposed methodology for nowcasting the demand and supply estimates of tourism', Economic \& Labour Market Review (October). Available at: www.statistics.gov.uk/elmr/10_10/

Buccellato T, Webber D, White S, Ritchie F and Begum S (2010) 'The economic impact of tourism across regions and nations of the UK', Economic \& Labour Market Review (May). Available at: www.statistics.gov.uk/CCl/article.asp? ID $=2415$

Jones C J, Munday M, Bryan J and Roberts A (2004), United Kingdom Tourism Satellite Account First Steps Project, a report for the Department of Culture, Media and Sport (DCMS)

Northern Ireland Tourism Board, Department for Enterprise, Trade and Investment (2007), Tourism in the Northern Ireland Economy. 
Stockholm Environment Institute (2008) 'Development of an Embedded Carbon Emissions Indicator - Producing a Time Series of Input-Output Tables and Embedded Carbon Dioxide Emissions for the UK by Using a MRIO Data Optimisation System' .

UNWTO, EUROSTAT, OECD (2008) Tourism Satellite Account: Recommended Methodological Framework (TSA:RMF), Madrid, Luxembourg, Paris.

Webber D, Buccellato T, and White S (2010) 'The impact of the global recession of tourists' spending in the UK, Economic \& Labour Market Review 2010 (August). 


\section{Annex: Tourism Satellite Accounts tables}

\section{Table 1 Inbound tourism expenditure by products and classes of visitors}

$£$ millions

\begin{tabular}{|c|c|c|c|}
\hline \multirow[b]{2}{*}{ Products } & \multicolumn{3}{|c|}{ Inbound Tourism Expenditure } \\
\hline & $\begin{array}{l}\text { Tourists (overnight } \\
\text { visitors) }\end{array}$ & $\begin{array}{l}\text { Excursionists (same- } \\
\text { day visitors) }\end{array}$ & Visitors \\
\hline Tourism Consumption Products & & & \\
\hline Accommodation services for visitors & 5126.0 & - & 5126.0 \\
\hline Food and beverage serving services & 4033.1 & 65.1 & 4098.2 \\
\hline Railway passenger transport services & 83.8 & 1.4 & 85.1 \\
\hline Road passenger transport services & 898.0 & 14.5 & 912.5 \\
\hline Water passenger transport services & 65.0 & 1.1 & 66.1 \\
\hline Air passenger transport services & 269.4 & 4.3 & 273.7 \\
\hline Transport equipment rental services & 100.1 & 1.6 & 101.7 \\
\hline Travel agencies and other reservation services & 50.7 & 0.0 & 50.7 \\
\hline 1.9 Cultural activities & 276.9 & 4.5 & 281.4 \\
\hline 1.10 Sport and recreation activities & 169.5 & 2.7 & 172.3 \\
\hline 1.11 Other consumption products & 4756.6 & 76.8 & 4833.4 \\
\hline Total & 15829.0 & 172.0 & 16001.0 \\
\hline
\end{tabular}

Sources: International Passenger Survey (IPS) 2006 and IPS Expenditure Trailer 1997, Family Spending Survey 2008 and Jones et al (2004) 


\begin{tabular}{|c|c|c|c|c|c|c|c|c|c|c|}
\hline \multirow{3}{*}{\multicolumn{2}{|c|}{ Consumption Products }} & \multicolumn{9}{|c|}{ Domestic Tourism Expenditure } \\
\hline & & \multicolumn{3}{|c|}{ Domestic Trips } & \multicolumn{3}{|c|}{ Outbound trips } & \multicolumn{3}{|c|}{ All types of trips } \\
\hline & & Overnight & Excursionists & Total & Tourists & Excursionists & Total & Tourists & Excursionists & Total \\
\hline \multicolumn{11}{|c|}{ Tourism Consumption Products } \\
\hline 2.1 & Accommodation services for visitors & $6,517.2$ & $x$ & $6,517.2$ & & & 0.0 & $6,517.2$ & - & $6,517.2$ \\
\hline 2.2 & Food and beverage serving services & $4,238.8$ & $15,232.0$ & $19,470.8$ & & & 0.0 & $4,238.8$ & $15,232.0$ & $19,470.8$ \\
\hline 2.3 & Railway passenger transport services & 564.1 & 128.6 & 692.8 & & & 481.8 & 564.1 & 128.6 & $1,174.6$ \\
\hline 2.4 & Road passenger transport services & $1,330.7$ & 280.8 & $1,611.6$ & & & $1,064.1$ & $1,330.7$ & 280.8 & $2,675.7$ \\
\hline 2.5 & Water passenger transport services & 438.0 & 52.9 & 491.0 & & & $2,467.4$ & 438.0 & 52.9 & $2,958.4$ \\
\hline 2.6 & Air passenger transport services & $1,814.4$ & 323.0 & $2,137.5$ & & & $9,422.2$ & $1,814.4$ & 323.0 & $11,559.6$ \\
\hline 2.7 & Transport equipment rental services & 163.2 & 694.6 & 857.8 & & & 0.0 & 163.2 & 694.6 & 857.8 \\
\hline 2.8 & $\begin{array}{l}\text { Travel agencies and other reservation } \\
\text { services }\end{array}$ & 791.4 & 218.2 & $1,009.6$ & & & $2,282.1$ & 791.4 & 218.2 & $3,291.7$ \\
\hline 2.9 & Cultural services & 762.7 & $3,737.7$ & $4,500.4$ & & & 0.0 & 762.7 & $3,737.7$ & $4,500.4$ \\
\hline \multirow[t]{2}{*}{2.10} & Sports and recreational services & 513.7 & $2,532.1$ & $3,045.8$ & & & 0.0 & 513.7 & $2,532.1$ & $3,045.8$ \\
\hline & & & & & & & & & 0.0 & 0.0 \\
\hline 2.11 & Other consumption products & $3,663.2$ & $22,378.6$ & $26,041.9$ & & & 0.0 & $3,663.2$ & $22,378.6$ & $26,041.9$ \\
\hline & TOTAL & $20,797.6$ & $45,578.6$ & $66,376.2$ & & & $15,717.6$ & $20,797.6$ & $45,578.6$ & $82,093.8$ \\
\hline
\end{tabular}

Sources: United Kingdom Tourism Survey 2006, Supply and Use Tables 2006, Family Spending Survey 2008, English Leisure Visits Survey 2005, Northern Ireland Tourist Board 2005, ONS price indices 2003-2006, Jones et al 2004. 


\section{Table 3 Outbound tourism expenditure by products and classes of visitors}

$£$ millions

\begin{tabular}{|c|c|c|c|}
\hline \multirow[b]{2}{*}{ Products } & \multicolumn{3}{|c|}{ Outbound tourism expenditure } \\
\hline & $\begin{array}{l}\text { Tourists (overnight } \\
\text { visitors) }\end{array}$ & $\begin{array}{l}\text { Excursionist } \\
\text { (same-day } \\
\text { visitors) }\end{array}$ & Visitors \\
\hline Tourism Consumption Products & & & \\
\hline 3.10 Accommodation services for visitors & $5,521.6$ & - & $5,521.6$ \\
\hline 3.20 Food and beverage serving services & $5,450.9$ & 107.1 & $5,557.9$ \\
\hline 3.30 Railway passenger transport services & 475.5 & 14.5 & 490.0 \\
\hline 3.40 Road passenger transport services & $1,517.4$ & 35.7 & 1553.1 \\
\hline 3.50 Water passenger transport service & $2,702.7$ & 10.3 & $2,713.0$ \\
\hline 3.60 Air passenger transport services & $6,971.3$ & 43.5 & $7,014.8$ \\
\hline 3.70 Transport equipment rental services & 612.7 & 4.4 & 617.2 \\
\hline 3.80 Travel agencies and other reservation services & 600.2 & 18.6 & 618.8 \\
\hline 3.90 Cultural services & 470.4 & 19.6 & 490.0 \\
\hline 3.10 Sports and recreational services & $5,360.9$ & 13.5 & $5,374.4$ \\
\hline 3.11 Other consumption products & $4,420.5$ & 39.8 & $4,460.3$ \\
\hline TOTAL & $34,104.0$ & 307.0 & $34,411.0$ \\
\hline
\end{tabular}

Sources: IPS 2006, SUT 2006, ABI 2006, Jones et al 2004 


\section{Table $4 \quad$ Internal tourism consumption by products}

$£$ millions

\begin{tabular}{|c|c|c|c|c|c|}
\hline \multirow[b]{2}{*}{ Products } & \multicolumn{3}{|c|}{ Internal tourism expenditure } & \multirow{2}{*}{$\begin{array}{c}\text { Other } \\
\text { components } \\
\text { of tourism } \\
\text { consumption }\end{array}$} & \multirow{2}{*}{$\begin{array}{c}\text { Internal } \\
\text { tourism } \\
\text { consumption }\end{array}$} \\
\hline & $\begin{array}{l}\text { Inbound } \\
\text { tourism } \\
\text { expenditur }\end{array}$ & $\begin{array}{l}\text { Domestic } \\
\text { tourism } \\
\text { expenditure }\end{array}$ & $\begin{array}{l}\text { Internal } \\
\text { tourism } \\
\text { xpenditure }\end{array}$ & & \\
\hline
\end{tabular}

\section{Tourism Consumption Products}

4.1 Accommodation services for visitors

$5126.0 \quad 6517.2 \quad 11643.2$

11643.2

(i) Second homes

4.2 Food and beverage serving services

$4,098.2 \quad 19,470.8 \quad 23,569.0$

$23,569.0$

4.3 Railway passenger transport services

$85.1 \quad 1,174.6 \quad 1,259.7$

$1,259.7$

4.4 Road passenger transport services

912.5

$2,675.7 \quad 3,588.1$

3588.1

4.5 Water passenger transport services

4.6 Air passenger transport services

$66.1 \quad 2,958.4 \quad 3,024.5$

$3,024.5$

$273.7 \quad 11,559.6 \quad 11,833.4$

$11,833.4$

4.7 Transport equipment rental services

$101.7 \quad 857.8 \quad 959.5$

959.5

4.8 Travel agencies and other reservation services

50.7

$3,291.7$

$3,342.4$

$3,342.4$

4.9 Cultural activities

281.4

$4,500.4$

$4,781.8$

$4,781.8$

4.10 Sport and recreation activities

172.3

$3,045.8$

$3,218.0$

$3,218.0$

4.11 Other consumption products

TOTAL 


\section{Table 5 Production accounts of tourism industries and other industries (at basic prices)}

$£$ millions

\begin{tabular}{|c|c|c|c|c|c|c|c|c|c|c|c|c|c|c|}
\hline \multirow[b]{2}{*}{ Product } & & \multicolumn{11}{|c|}{ Tourism Industries } & \multirow[b]{2}{*}{ Other Industries } & \multirow{2}{*}{$\begin{array}{c}\text { Output of } \\
\text { domestic } \\
\text { producers (at } \\
\text { basic prices) }\end{array}$} \\
\hline & & $\begin{array}{l}\text { Accommodation } \\
\text { for visitors }\end{array}$ & $\begin{array}{l}\text { Food and } \\
\text { beverage } \\
\text { serving industry }\end{array}$ & $\begin{array}{l}\text { Railway } \\
\text { passenger } \\
\text { transport }\end{array}$ & $\begin{array}{l}\text { Road passenger } \\
\text { transport }\end{array}$ & $\begin{array}{l}\text { Water } \\
\text { passenger } \\
\text { transport }\end{array}$ & $\begin{array}{l}\text { Air passenger } \\
\text { transport }\end{array}$ & $\begin{array}{l}\text { Transport } \\
\text { equipment } \\
\text { rental }\end{array}$ & $\begin{array}{l}\text { Travel agencies } \\
\text { and other } \\
\text { reservation } \\
\text { services industry }\end{array}$ & $\begin{array}{l}\text { Cultural } \\
\text { Industry }\end{array}$ & $\begin{array}{l}\text { Sports and } \\
\text { recreational } \\
\text { industry }\end{array}$ & TOTAL & & \\
\hline 5.1 & $\begin{array}{l}\text { Accommodation services } \\
\text { for visitors }\end{array}$ & $15,861.5$ & $1,820.3$ & 1.5 & 23.0 & 21.8 & 32.9 & 29.7 & 105.1 & 9.5 & 29.0 & $17,934.3$ & 281.3 & $18,215.6$ \\
\hline 5.2 & $\begin{array}{l}\text { Food and beverage } \\
\text { serving services }\end{array}$ & $5,894.1$ & $47,531.0$ & 1.5 & 23.0 & 21.8 & 32.9 & 29.7 & 105.1 & 97.8 & 299.0 & $54,035.9$ & $4,593.0$ & $58,628.9$ \\
\hline 5.3 & $\begin{array}{l}\text { Railway passenger } \\
\text { transport services }\end{array}$ & 0.0 & 0.0 & $9,051.9$ & 0.0 & 0.0 & 0.0 & 0.0 & 0.0 & 0.0 & 0.0 & $9,051.9$ & 0.0 & $9,051.9$ \\
\hline 5.4 & $\begin{array}{l}\text { Road passenger transport } \\
\text { services }\end{array}$ & 0.0 & 0.0 & 177.7 & $38,288.3$ & 0.0 & 0.0 & 0.0 & 0.0 & 0.0 & 0.0 & $38,465.9$ & $2,307.9$ & $40,773.8$ \\
\hline 5.5 & $\begin{array}{l}\text { Water passenger transport } \\
\text { services }\end{array}$ & 0.0 & 0.0 & 0.0 & 0.0 & $8,762.2$ & 0.0 & 0.0 & 0.0 & 0.0 & 0.0 & $8,762.2$ & 0.0 & $8,762.2$ \\
\hline 5.6 & $\begin{array}{l}\text { Air passenger transport } \\
\text { services }\end{array}$ & 0.0 & 0.0 & 0.0 & 0.0 & 0.0 & $16,677.2$ & 0.0 & 0.0 & 0.0 & 0.0 & $16,677.2$ & 0.0 & $16,677.2$ \\
\hline 5.7 & $\begin{array}{l}\text { Transport equipment } \\
\text { rental services }\end{array}$ & 0.0 & 0.0 & 0.0 & 0.0 & 0.0 & 0.0 & $11,667.9$ & 0.0 & 0.0 & 0.0 & $11,667.9$ & 0.0 & $11,667.9$ \\
\hline 5.8 & $\begin{array}{l}\text { Travel agencies and other } \\
\text { reservation services }\end{array}$ & 0.0 & 0.0 & 0.0 & 0.0 & 0.0 & 0.0 & 0.0 & $41,320.8$ & 0.0 & 0.0 & $41,320.8$ & 0.0 & $41,320.8$ \\
\hline 5.9 & Cultural activities & 0.0 & 0.0 & 0.0 & 0.0 & 0.0 & 0.0 & 0.0 & 0.0 & $13,641.5$ & 0.0 & $13,641.5$ & 0.0 & $13,641.5$ \\
\hline 5.10 & $\begin{array}{l}\text { Sport and recreation } \\
\text { activities }\end{array}$ & 0.0 & 0.0 & 0.0 & 0.0 & 0.0 & 0.0 & 0.0 & 0.0 & 0.0 & $41,714.4$ & $41,714.5$ & 0.0 & $41,714.5$ \\
\hline \multirow[t]{4}{*}{5.11} & Other Products & 40.7 & 92.2 & 7.5 & 115.8 & 221.1 & 263.0 & 297.2 & $1,052.5$ & $1,776.5$ & $5,432.4$ & $9,299.0$ & $2,115,073.8$ & $2,124,372.7$ \\
\hline & $\begin{array}{l}\text { TOTAL OUTPUT (at basic } \\
\text { prices) }\end{array}$ & $21,796.3$ & $49,443.7$ & $9,240.0$ & $38,450.0$ & $9,027.0$ & $17,006.0$ & $12,024.5$ & $42,583.5$ & $15,525.2$ & $47,474.8$ & $262,571.0$ & $2,122,256.0$ & $2,384,827.0$ \\
\hline & $\begin{array}{l}\text { TOTAL INTERMEDIATE } \\
\text { CONSUMPTION (at } \\
\text { purchasers price) }\end{array}$ & $11,466.0$ & $26,010.0$ & $6,017.0$ & $21,999.0$ & $5,952.0$ & $10,381.0$ & $7,374.8$ & $26,117.2$ & $7,594.3$ & $23,222.7$ & $146,134.0$ & $1,061,461.0$ & $1,207,595.0$ \\
\hline & $\begin{array}{l}\text { TOTAL GROSS VALUE } \\
\text { ADDED (at basic prices) }\end{array}$ & $10,330.3$ & $23,433.7$ & $3,223.0$ & $16,451.0$ & $3,075.0$ & $6,625.0$ & $4,649.7$ & $16,466.3$ & $7,930.9$ & $24,252.1$ & $116,437.0$ & $1,060,795.0$ & $1,177,232.0$ \\
\hline
\end{tabular}

Sources: Supply and Use Tables 2006, Stockholm Environment Institute 2008, Jones et al 2004, ABI 2006 


\section{Table 6 Total domestic supply and internal tourism consumption (at purchasers prices)}

$£$ millions

\begin{tabular}{|c|c|c|c|c|c|c|c|c|c|c|c|c|c|c|c|c|c|c|c|}
\hline \multirow{2}{*}{\multicolumn{2}{|c|}{ Products }} & \multicolumn{11}{|c|}{ Tourism Industries } & \multirow[b]{2}{*}{$\begin{array}{c}\text { Other } \\
\text { Industries }\end{array}$} & \multirow[b]{2}{*}{$\begin{array}{l}\text { Output of } \\
\text { domestic } \\
\text { producers } \\
\text { (at basic } \\
\text { prices) }\end{array}$} & \multirow[b]{2}{*}{ Imports } & \multirow[b]{2}{*}{$\begin{array}{l}\text { Taxes less } \\
\text { subsidies on } \\
\text { products } \\
\text { nationally } \\
\text { produced and } \\
\text { imported }\end{array}$} & \multirow[b]{2}{*}{$\begin{array}{c}\text { Domestic } \\
\text { supply (at } \\
\text { purchasers' } \\
\text { prices) }\end{array}$} & \multirow[b]{2}{*}{$\begin{array}{c}\text { Internal } \\
\text { tourism } \\
\text { consumptio } \\
n\end{array}$} & \multirow[b]{2}{*}{$\begin{array}{c}\text { Tourism } \\
\text { ratios } \\
(\%)\end{array}$} \\
\hline & & $\begin{array}{l}\text { Accommodation } \\
\text { for visitors }\end{array}$ & $\begin{array}{l}\text { Food and } \\
\text { beverage } \\
\text { seving } \\
\text { industry }\end{array}$ & $\begin{array}{l}\text { Railway } \\
\text { passenger } \\
\text { transport }\end{array}$ & $\begin{array}{l}\text { Road } \\
\text { passenger } \\
\text { transport }\end{array}$ & $\begin{array}{l}\text { Water } \\
\text { passenger } \\
\text { transport }\end{array}$ & $\begin{array}{c}\text { Air } \\
\text { passenger } \\
\text { transport }\end{array}$ & $\begin{array}{l}\text { Transport } \\
\text { equipment } \\
\text { rental }\end{array}$ & $\begin{array}{l}\text { Travel } \\
\text { agencies } \\
\text { and other } \\
\text { reservation } \\
\text { services } \\
\text { industry }\end{array}$ & $\begin{array}{l}\text { Cultural } \\
\text { Industry }\end{array}$ & $\begin{array}{l}\text { Sports and } \\
\text { recreational } \\
\text { industry }\end{array}$ & TOTAL & & & & & & & \\
\hline 6.1 & $\begin{array}{l}\text { Accommodation } \\
\text { services for visitors }\end{array}$ & $15,861.5$ & $1,820.3$ & 1.5 & 23.0 & 21.8 & 32.9 & 29.7 & 105.1 & 9.5 & 29.0 & $17,934.3$ & 281.3 & $18,215.6$ & $4,275.7$ & $3,825.4$ & $26,316.7$ & $11,643.2$ & 44.24 \\
\hline 6.2 & $\begin{array}{l}\text { Food and beverage } \\
\text { serving services }\end{array}$ & $5,894.1$ & $47,531.0$ & 1.5 & 23.0 & 21.8 & 32.9 & 29.7 & 105.1 & 97.8 & 299.0 & $54,035.9$ & $4,593.0$ & $58,628.9$ & $9,699.3$ & $8,677.6$ & $77,005.8$ & $23,569.0$ & 30.61 \\
\hline 6.3 & $\begin{array}{l}\text { Railway passenger } \\
\text { transport services }\end{array}$ & 0.0 & 0.0 & $9,051.9$ & 0.0 & 0.0 & 0.0 & 0.0 & 0.0 & 0.0 & 0.0 & $9,051.9$ & 0.0 & $9,051.9$ & 618.0 & $-2,963.0$ & $6,706.9$ & $1,259.7$ & 18.78 \\
\hline 6.4 & $\begin{array}{l}\text { Road passenger } \\
\text { transport services }\end{array}$ & 0.0 & 0.0 & 177.7 & $38,288.3$ & 0.0 & 0.0 & 0.0 & 0.0 & 0.0 & 0.0 & $38,465.9$ & 2307.9 & $40,773.8$ & $1,959.0$ & 394.0 & $43,126.8$ & $3,588.1$ & 8.32 \\
\hline 6.5 & $\begin{array}{l}\text { Water passenger } \\
\text { transport services }\end{array}$ & 0.0 & 0.0 & 0.0 & 0.0 & $87,62.2$ & 0.0 & 0.0 & 0.0 & 0.0 & 0.0 & $87,62.2$ & 0.0 & $87,62.2$ & $3,422.0$ & -196.0 & $11,988.2$ & $3,024.5$ & 25.23 \\
\hline 6.6 & $\begin{array}{l}\text { Air passenger transport } \\
\text { services }\end{array}$ & 0.0 & 0.0 & 0.0 & 0.0 & 0.0 & $16,677.2$ & 0.0 & 0.0 & 0.0 & 0.0 & $16,677.2$ & 0.0 & $16,677.2$ & $8,848.0$ & 808.0 & $26,333.2$ & $11,833.4$ & 44.94 \\
\hline 6.7 & $\begin{array}{l}\text { Transport equipment } \\
\text { rental services }\end{array}$ & 0.0 & 0.0 & 0.0 & 0.0 & 0.0 & 0.0 & $11,667.9$ & 0.0 & 0.0 & 0.0 & $11,667.9$ & 0.0 & $11,667.9$ & 343.3 & 107.9 & $12,119.1$ & 959.5 & 7.92 \\
\hline 6.8 & $\begin{array}{l}\text { Travel agencies and } \\
\text { other reservation } \\
\text { services }\end{array}$ & 0.0 & 0.0 & 0.0 & 0.0 & 0.0 & 0.0 & 0.0 & $41,320.8$ & 0.0 & 0.0 & $41,320.8$ & 0.0 & $41,320.8$ & $1,215.7$ & 382.1 & $42,918.6$ & 3,342.4 & 7.79 \\
\hline 6.9 & Cultural activities & 0.0 & 0.0 & 0.0 & 0.0 & 0.0 & 0.0 & 0.0 & 0.0 & $13,641.5$ & 0.0 & $13,641.5$ & 0.0 & $13,641.5$ & $1,822.9$ & $1,251.9$ & $16,716.2$ & $47,81.8$ & 28.61 \\
\hline 6.1 & $\begin{array}{l}\text { Sport and recreation } \\
\text { activities }\end{array}$ & 0.0 & 0.0 & 0.0 & 0.0 & 0.0 & 0.0 & 0.0 & 0.0 & 0.0 & $41,714.4$ & $41,714.5$ & 0.0 & $41,714.5$ & $5,574.1$ & $3,828.1$ & $51,116.7$ & $32,18.0$ & 6.30 \\
\hline 6.1 & Other Products & 40.7 & 92.2 & 7.5 & 115.8 & 221.1 & 263.0 & 297.2 & $10,52.5$ & $17,76.5$ & $5,432.4$ & $9,299.0$ & $2,115,073.8$ & $2,124,372.7$ & $381,810.0$ & $12,8512.0$ & 2,634,694.7 & $30,875.2$ & 1.17 \\
\hline & $\begin{array}{l}\text { TOTAL OUTPUT (at } \\
\text { basic prices) }\end{array}$ & $21,796.3$ & $49,443.7$ & $9,240.0$ & $38,450.0$ & $9,027.0$ & $17,006.0$ & $12,024.5$ & $42,583.5$ & $15,525.2$ & $47,474.8$ & $26,2571.0$ & $2,122,256.0$ & $2,384,827.0$ & $419,588.0$ & $144,628.0$ & $2,949,043.0$ & $98,094.8$ & 3.33 \\
\hline & $\begin{array}{l}\text { TOTAL } \\
\text { INTERMEDIATE } \\
\text { CONSUMPTION (at } \\
\text { purchasers price) }\end{array}$ & $11,466.0$ & $26,010.0$ & $6,017.0$ & $21,999.0$ & $5,952.0$ & $10,381.0$ & $7,374.8$ & $26,117.2$ & $7,594.3$ & $23,222.7$ & $146,134.0$ & $1,061,461.0$ & $1,207,595.0$ & & & & & \\
\hline & $\begin{array}{l}\text { TOTAL GROSS } \\
\text { VALUE ADDED (at } \\
\text { basic prices) }\end{array}$ & $10,330.3$ & $23,433.7$ & $3,223.0$ & $16,451.0$ & $3,075.0$ & $6,625.0$ & $4,649.7$ & $16,466.3$ & $7,930.9$ & $24,252.1$ & $116,437.0$ & $1,060,795.0$ & $1,177,232.0$ & & & & & \\
\hline
\end{tabular}

Sources: Same as Tables 1,2 and 5 